\title{
PROSPEK PENGGUNAAN KAYU RENDAH LIGNIN HASIL TEKNOLOGI DNA UNTUK PROSES PULPING YANG EFISIEN DAN RAMAH LINGKUNGAN
}

\section{POTENTIAL APPLICATION OF GENETIC ENGINEERED LOW LIGNIN WOOD TOWARD EFFICIENT AND ENVIRONMENTALLY FRIENDLY PULPING PROCESS}

\author{
N. Sri Hartati ${ }^{1}$
}

(Diterima tanggal 05-02-2016; Disetujui tanggal 15-02-2016)

\begin{abstract}
ABSTRAK
Pemisahan lignin dari selulosa membutuhkan input bahan kimia dan energi yang tinggi yang berdampak pada tingginya biaya produksi dan resiko ekologi yang ditimbulkannya. Keberadaan lignin pada sel tanaman merupakan faktor pembatas efisiensi pengolahan material lignoselulosa menjadi produk-produk industri berbahan dasar kayu termasuk pulp baik secara kimia maupun biologis. Kadar dan komposisi lignin yang terkandung dalam tanaman akan mempengaruhi efisiensi proses pulping. Oleh karena itu bahan baku pulp dengan kadar lignin rendah atau yang memiliki komposisi lignin dengan reaktivitas tinggi lebih mudah dipisahkan dari selulosa, sehingga akan sangat menguntungkan bagi industri pulp karena akan menghemat energi dan biaya. Pada tulisan ini ditinjau aspek produksi dalam industri pulp terkait dengan pengelolaan fungsi lingkungan, teknologi alternatif untuk modifikasi kadar lignin kayu melalui teknologi DNA untuk menunjang produksi pulp yang efisien dan ramah lingkungan.
\end{abstract}

Kata kunci: Lignin, kayu, pulp, rekayasa genetika,

\begin{abstract}
Separation of lignin from cellulose requires high input of chemicals and energy resulted in high cost production and high ecological risks. The presence of lignin in plant cells is a factor limiting the efficiency of processing lignocellulosic materials of wood-based industries including pulp and paper industry either chemically or biologically (biopulping) process using white rot fungi. Lignin content and composition affect the efficiency of pulping process. Low-lignin wood or wood containing more reactive lignin which means syringyl content is higher than guaiacyl are more easily separated from cellulose. Therefore, it would be advantage to improve the efficiency process of pulp and paper industry. In the following review we discuss background on pulp industry processes related to environmental safety management, and modification lignin content through genetic engineering concerning its potential application in efficient and environmental friendly pulping process.
\end{abstract}

Key words: Lignin, wood, pulp, genetic engineering

\section{PENDAHULUAN}

Kayu merupakan material lignoselulosa yang memiliki nilai ekonomi tinggi dengan pemanfaatan yang luas mencakup kayu konstruksi, kayu lapis, pulp dan kertas hingga perkembangan terkini yang telah memulai memanfaatkan kayu sebagai bahan baku bioetanol. Khusus untuk industri pulp dan kertas, hingga kini kayu masih diandalkan sebagai bahan baku utama. Industri pulp terus berkembang dan produksinya cenderung meningkat dari tahun ke tahun seiring dengan bertambahnya konsumsi kertas dunia. Secara umum, produksi kertas dan pulp dunia pada

${ }^{1}$ Pusat Penelitian Bioteknologi LIPI - Jl. Raya Bogor Km 46 Cibinong 16911 Telp. 021-8754587 Email: Hartati12@yahoo.com 
tahun 2004 adalah sekitar 360 juta ton dan diperkirakan akan meningkat hingga 494 juta ton pada 2020 [1].

Potensi Indonesia masih sangat mendukung perkembangan sektor industri pulp dunia dengan mengedepankan visi kelestarian lingkungan. Berbagai upaya telah dilakukan untuk meningkatkan produksi pulp ramah lingkungan antara lain modifikasi proses bleaching tanpa senyawa organik terklorinasi (AOX). Hal tersebut berkaitan dengan salah satu aspek kebijakan pengelolaan lingkungan hidup yang berkenaan dengan baku mutu lingkungan yaitu pengurangan produksi limbah, dalam rangka peningkatan efisiensi produksi dengan maksud untuk mengurangi produksi limbah yang berupa limbah bahan berbahaya dan beracun (B3), cair, padat dan gas. Pemilihan bahan baku, pengembangan teknologi, pemanfaatan ulang dan lain-lain dapat dilakukan dalam rangka peningkatan efisiensi produksi [2].

Proses industri pulp yang memanfaatkan kayu sebagai bahan baku umumnya menggunakan proses sulfat/Kraft. Proses ini memiliki keuntungan diantaranya dapat mengolah berbagai jenis kayu baik yang sejenis maupun campuran, waktu pengolahan yang relatif pendek dan menghasilkan pulp dengan kualitas tinggi, yaitu dihasilkannya serat yang kuat. Namun demikian, pulp yang dihasilkan berwarna gelap sehingga membutuhkan banyak bahan pemutih dan menghasilkan limbah berupa bahan organik terklorinasi yang bersifat toksik diantaranya dioksin [3].

Warna gelap pada pulp umumnya disebabkan oleh lignin, salah satu komponen utama penyusun kayu yang tergolong ke dalam senyawa fenolik yang sangat mudah teroksidasi. Pada sisi lain, limbah organik terklorinasi yang dihasilkan dari proses bleaching sulit untuk didegradasi atau didaur ulang sehingga berpotensi sebagai bahan pencemar yang membahayakan lingkungan. Lebih dari sepuluh tahun terakhir ini, berbagai cara meminimalkan limbah dalam industri pulp telah ditempuh yaitu melalui pengolahan pulp dengan memanfaatkan mikroba (biopulping) maupun modifikasi proses bleaching. Modifikasi proses bleaching yaitu Totally Chlorin Free (TCF) bleaching yang menggunakan bahan kimia hidrogen peroksida dan ozon [4] telah berhasil menurunkan toksisitas air limbah menjadi lebih rendah dibanding proses yang umum dipakai sebelumnya yaitu Elemental Chlorin Free (ECF). Namun demikian, modifikasi proses bleaching pulp bersifat menurunkan saja dan tidak dapat menghilangkan limbah berbahaya sama sekali. Keberadaan lignin merupakan faktor pembatas efisiensi pengolahan material lignoselulosa menjadi produk-produk industri termasuk pulp baik yang diproses secara kimia maupun biologis (biopulping) menggunakan jamur pelapuk putih Asosiasi lignin dengan selulosa membentuk suatu matriks hidrofobik yang membatasi efektifitas kerja enzimenzim hidrolitik yang berperan dalam proses biopulping.

Pengurangan limbah dapat pula dilakukan melalui subtitusi atau pemilihan bahan baku yang mendukung efisiensi proses bleaching. Selain itu struktur lignin mempengaruhi proses kimia dan fisika pulping kayu dan penggunaan serat yang dihasilkannya. Dengan demikian penggunaan bahan baku kayu dengan kadar lignin rendah atau yang memiliki komposisi lignin dengan reaktivitas tinggi yaitu yang rasio 
siringil ligninnya lebih tinggi sehingga lebih mudah dipisahkan dari selulosa, akan sangat menguntungkan bagi industri pengolahan pulp karena akan menghemat energi dan biaya disamping dapat menekan limbah berbahaya.

Bahan baku kayu rendah lignin dapat dihasilkan melalui pengelolaan praktek silvikultur. Di samping itu, ketersediaan sumber daya genetik pohon dengan kadar lignin sesuai dengan kebutuhan juga akan sangat mendukung efisiensi industri pulp dan kertas. Perkembangan teknik biologi molekulermemberikan sumbangan yang berarti untuk aplikasi teknologi DNA (Deoxyribonucleic acid Deoxyribonucleic acid) atau dikenal juga dengan rekayasa genetik guna mengontrol biosintesis komponen dinding sel tanaman termasuk lignin. Studi molekuler mengenai enzimenzim yang terkait dengan biosintesis lignin telah dimulai sejak tahun 1990-an dari tanaman model Arabidopsis thaliana dan tembakau (Nicotiana tabacum) hingga tanaman berkayu seperti poplar (Pupulus alba) dan pinus (Pinus taeda). Tanaman berkayu transgenik rendah lignin pertama adalah antisense 4-Coumarate Coenzim A ligase (4CL) poplar yang dilaporkan oleh kelompok peneliti dari North Carolina University. Berbagai macam gen terkait biosintesis lignin dari berbagai tanaman saat ini telah terdokumentasi pada situs gene bank (www.ncbi.nlm.nih.gov). Selain itu studi mengenai fungsi gen terkait biosintesis lignin dengan memanfaatkan teknik transgenesis baik yang bersifat menurunkan ekspresi gen (up regulation) maupun meningkatkan ekspresi gen (down regulation) telah banyak dilaporkan.
Pada tulisan ini ditinjau aspek-aspek produksi dalam industri pulp berkenaan dengan pengelolaan fungsi lingkungan yang lestari, teknologi alternatif untuk modifikasi bahan baku melalui teknologi yang dapat menunjang efisiensi produksi dan ramah lingkungan serta bahasan mengenai ekolabel terkait dengan perdagangan bebas dan sistem manajemen hutan lestari. Tinjauan ilmiah ini bertujuan untuk memberikan informasi mengenai prospek penggunaan kayu rendah lignin untuk menunjang produksi pulp yang efisien dan ramah lingkungan dengan memanfaatkan Teknologi DNA rekombinan sebagai metoda mutasi genetik terarah untuk menghasilkan pohon dengan komposisi kayu dengan kadar atau rasio lignin yang mudah diproses.

\section{PERMASALAHAN PADA INDUSTRI PULPDANKERTASSERTAALTERNATIF SOLUSI}

Pabrik pulp terdiri atas rangkaian instalasi luas dan rumit berupa tabung-tabung besar, cerobong tinggi dan kolam limbah yang semuanya dihubungkan dengan pipa-pipa. Luas instalasi dapat mencapai 200 ha. Bahan baku yang digunakan umumnya kayu dari beberapa jenis seperti Eucalyptus, pinus merkusi dan kayu campuran (mixed tropical hardwood), disamping ada pula pabrik pulp yang menggunakan jerami atau kertas daur ulang sebagai bahan bakunya.

Sejalan dengan peningkatan kebutuhan pulp dan kertas dunia, industri pulp dan kertas dituntut untuk meningkatkan efisiensi produksi dengan tetap menjaga kelestarian sumber bahan baku. Selain itu tuntutan mutu lingkungan dengan menekan pencemaran 
industri, mendorong penelitian yang sangat intensif di bidang teknologi proses maupun rekayasa jenis tanaman bahan baku pulp. Modifikasi bahan baku pulp dengan meminimalkan faktor-faktor pembatas pada proses pembuatan pulp akan meningkatkan efisiensi proses.

Lignin merupakan senyawa fenolik berupa heteropolimer kompleks yang terdapat pada dinding sel dan berperan penting dalam strategi adaptasi tanaman terhadap cekaman biotik seperti hama dan penyakit. Akan tetapi dari perspektif agroindustri, lignin memiliki dampak negatif dalam pemanfaatan biomassa untuk produk pulp dan kertas, industri tekstil, produksi pakan ternak dan produksi biofuel [5]. Kadar dan komposisi lignin pada setiap tanaman bervariasi tergantung umur tanaman, jenis sel dan jaringan serta lokasi tumbuh. Kadar dan komposisi lignin pada setiap tanaman bervariasi tergantung umur tanaman, jenis sel dan jaringan serta lokasi tumbuh. Berdasarkan klasifikasi komponen kimia kayu Indonesia, prosentase kadar lignin kayu dikelompokkan menjadi tiga kategori yaitu lignin tinggi (33\%), lignin sedang (18-33\%) dan lignin rendah (18\%) [6]. Distribusi lignin di dalam dinding sel dan pada bagian pohon yang berbeda tidak sama. Kadar lignin yang tinggi adalah khas untuk bagian batang yang paling rendah dan paling dalam [7]. Perbedaan kadar lignin tidak saja terdapat pada bagian pohon yang berbeda tetapi juga tergantung provenans, seperti pada Acacia mangium yang kadar ligninnya pada tiga provenans yaitu Queensland, Papua New Guinea dan Indonesia Bagian Timur bervariasi yaitu 21.98, 24.54 dan 23.33\% [8]. Demikian pula pada kayu sengon, analisis kayu sengon yang dikoleksi dari daerah Cibinong, Cikampek, Tasikmalaya dan Yogyakarta menunjukkan bahwa kadar lignin sengon berbeda dengan kisaran (16.58$35.59 \%$ ) [9]. Berdasarkan komposisi unit strukturalnya, lignin diklasifikasikan kedalam beberapa tipe. Lignin pada softwood (kayu daun jarum) atau disebut lignin guaiasil atau $\mathrm{G}$ lignin sebagian besar disusun oleh unit guaiasil (sekitar 90\%) dan $p$-kumaril alkohol (sekitar 10\%). Lignin pada hardwood (kayu daun lebar) atau disebut lignin guaiasil siringil atau G-S lignin disusun oleh unit guaiasil dan siringil dengan perbandingan tertentu, tergantung dari jenis kayu, umur kayu, tempat tumbuh dan iklim [10].

Pulp coklat (unbleached pulp) yang merupakan hasil pencucian kemudian disaring, diputihkan, atau dikelantang pada unit pemutih (bleaching) yang umumnya dilakukan dalam tiga hingga enam tahap. Pada proses pemutihan menggunakan zat-zat kimia dari golongan klorin terutama $\mathrm{Cl}_{2}$, akan bereaksi dengan lignin menghasilkan limbah berupa senyawa organoklorin yang umumnya beracun. Bleaching pulp ditinjau dari segi proses industri sangat penting karena derajat putih pulp tidak hanya merupakan standar kualitas yang digunakan oleh industri tetapi juga sebagai salah satu kriteria pemilihan oleh konsumen. Pengolahan pulp secara biologi merupakan proses yang memanfaatkan mikroba yaitu jamur pelapuk putih (white rot fungi) untuk melemahkan struktur kayu melalui cara degradasi lignin sehingga akan mengurangi pemakaian bahan kimia dan energi didalam pemisahan serat [3].

Program pengurangan limbah dalam industri kertas yang efektif akan mengurangi biaya produksi dan beban pengelolaan limbah 
berbahaya sehingga akan meningkatkan efisiensi dan kualitas produk. Teknik pengurangan limbah yang dapat dilakukan adalah penggantian (substitusi) bahan baku sebagai salah satu alternatif pengurangan limbah selain yang terkait langsung dengan proses produksi seperti perencanaan produksi dan tahapannya, penyesuaian peralatan, proses atau modifikasi serta pemisahan limbah dan daur ulang limbah [11]. Substitusi bahan baku yang dapat diterapkan untuk efisiensi produksi pulp adalah penggunaan bahan baku dengan komposisi lignin yang memudahkan proses pulping sehingga dapat menekan biaya produksi.

Selain pengurangan limbah melalui modifikasi proses bleaching menuju zero AOX, ada pula biopulping yaitu pemanfaatan mikroba dalam pengolahan pulp ataupun biobleaching yang sudah dikembangkan untuk mengurangi resiko pencemaran oleh pabrik pulp. Pengolahan pulp secara biologi adalah suatu proses yang memanfaatkan mikroba untuk melemahkan struktur kayu melalui degradasi lignin. Pengurangan lignin di dalam serpih kayu akan mengurangi pemakaian bahan kimia dan energi didalam pemisahan serat. Jenis mikroba yang digunakan adalah jamur pelapuk putih (white rot fungi) yang diketahui mampu mendegradasi lignin. Penelitian mengenai biopulping telah banyak dilakukan diantaranya peranan jamurpelapuk putih dalam biodelignifikasi kayu sengon [3], studi regulasi enzim pendegradasi lignin dari Lentinus squarrosulus (Mont.) Singer dan Psathyrella atroumbonata Peglen [12] dan studi pemutusan alkil-aril lignin fenolik $\beta$-O-4 lignin oleh $\mathrm{Mn}(\mathrm{II})$-peroksida yang diisolasi dari Pleurotus astreatus [13]. Jenis fungi mesofil lain yang telah banyak dipelajari yang memiliki kemapuan untuk biodegradasi selulosa, hemiselulosa dan lignin diantaranya adalah Thricoderma reesei dan Phanerochaete chrysosporium [14]. Biobleaching dengan menggunakan jamur pelapuk putih dapat dilakukan dengan memanfaatkan enzim lakase $[15,16]$.

Disamping modifikasi proses bleaching, pemilihan atau substitusi bahan baku untuk proses yang lebih efisien juga juga dapat diterapkan untuk tujuan pengelolaan fungsi lingkungan yang lebih baik. Modifikasi kadar lignin kayu baik berupa penurunan kadar lignin total maupun merubah komposisinya agar lebih peka terhadap proses pulping diharapkan akan berdampak terhadap peningkatan efisiensi peleraian lignin dari selulosa dan menurunkan kebutuhan bahan pemutih pulp.

KAYU RENDAH LIGNIN HASIL REKAYASA GENETIK SEBAGAI ALTERNATIF BAHAN BAKU PULP YANG EFISIEN

Lignin adalah polimer aromatik yang merupakan salah satu komponen dinding sel tanaman (17-33\%) di samping selulosa. Senyawa ini dikelompokkan ke dalam 3 (tiga) grup berdasarkan unit monomer penyusunnya yaitu gymnosperm lignin (disusun oleh monomer coniferyl alkohol), angiosferm lignin (disusun oleh monomer coniferyl alkohol dan sinapil alkohol) serta grass lignin (terdiri dari campuran monomer coniferyl alkohol, sinapil alkohol dan $\rho$-coumaril alkohol) [17]. Lignin adalah polimer aromatik yang merupakan salah satu komponen dinding sel yang berasosiasi dengan selulosa. Peranan lignin 
didalam pertumbuhan dan perkembangan tanaman sangatlah penting diantaranya membantu konduksi air melalui elemen trakeari, menyokong kekuatan mekanik sel dan tegakan pohon secara umum, serta melindungi dari serangan patogen.

Kandungan lignin pada sel tanaman (monomer guaiasil dan siringil) berpengaruh terhadap pelepasan dan hidrolisis polisakarida. Upaya mengurangi kadar lignin kayu sengon hingga mencapai kadar tertentu (rendah) atau modifikasi untuk mengubah komposisi G/S (guaiasil dan siringil) lignin sehingga lebih mudah dipisahkan dari selulosa, akan sangat menguntungkan bagi industri pengolahan pulp karena akan menghemat energi dan biaya di samping dapat menekan limbah berbahaya. Karakteristik fisik dan kimia dari biomassa meliputi dimensi serat, kadar selulosa dan lignin dapat mempengaruhi kesesuaiannya untuk produk kertas. Analisis komposisi kimia bahan baku kayu dengan kadar lignin berbeda telah dibandingkan untuk jenis kayu berdaun lebar dan kayu berdaun jarum. Kayu dengan kadar lignin yang lebih tingi (>25\%) yaitu rumput zebra (Miscanthus x giganteus), switchgrass (Panicum virgatum) dan kayu pohon almond (Prunus dulcis L.) membutuhkan waktu pulping dan bahan kimia yang lebih banyak dibanding biomassa lainnya [18].

Siringil lignin yang tersusun atas monomer sinapil alkohol lebih peka terhadap degradasi kimia maupun enzimatik dibanding guasil lignin, karena unit posisi C5 aromatik pada guasil bebas berikatan antar karbon. Ferulate 5-hydroxylase ( $\mathrm{F} 5 \mathrm{H})$ terlibat dalam jalur sintesis 5-hidroksi koniferaldehid berupa prekursor sinapilalkohol sebagai penyusun siringil lignin. Over ekspresi ferulate 5-hydroxylase Arabidopsis pada poplar, menghasilkan kayu poplar transgenik dengan kadar siringil lignin tinggi yang dapat meningkatkan efisiensi proses pulping yaitu dalam hal peleraian selulosa dari lignin [19]. Over ekspresi F5H sweetgum di bawah kontrol promotor xylem-specific Pt4CLIP pada aspen (Populus tremula) transgenik berhasil meningkatkan rasio siringil/guaiasil (S/G) hingga 2.5 kali [20]. Demikian pula overekspresi ferulate 5-hydroxylase Arabidopsis pada poplar, menghasilkan kayu poplar transgenik dengan kadar siringil lignin tinggi yang dapat meningkatkan efisiensi proses pulping yaitu dalam hal peleraian selulosa dari lignin [21]. Pendekatan rekayasa metabolik serupa yaitu overekspresi F5H dapat pula diterapkan pada tanaman lain untuk menghasilkan kayu dengan kadar siringil lignin tinggi untuk proses pulping yang lebih efisien.

Perbaikan sifat tanaman dengan cara konvensional yaitu melalui hibridisasi seksual (persilangan) akan membutuhkan waktu lama terutama karena panjangnya siklus hidup tanaman kehutanan. Dengan demikian perlu dicari cara lain diantaranya melalui usaha perbaikan sifat tanaman melalui teknologi DNA atau rekayasa genetika untuk memodifikasi kadar lignin kayu sengon dalam waktu relatif singkat. Penelitian mengenai transgenik tanaman tinggi ditemukan pada lebih dari 100 laporan yang meliputi ketahanan terhadap herbisida dan serangga [22] dan modifikasi lignin tanaman berkayu melalui represi ekspresi enzim yang berkaitan dengan biosintesis lignin [23, 24, 25,26]. Pada beberapa tanaman telah diketahui enzim- 
enzim yang berkaitan dengan biosintesis lignin diantaranya phenylalanine ammonia-lyase (PAL) [27], o-methyltransferase (CCoAoMT) [28, 29], 4-coumarate CoA ligase (4CL) [30, 31, 32, 33], cinnamoyl-CoA reductase (CCR) dan cinnamyl alcohol dehydrogenase (CAD) [34]. Keterlibatan enzim-enzim tersebut dalam jalur biosintesis lignin dapat dilihat pada Gambar 1.

Pendekatan untuk menekan biosintesis lignin adalah dengan memanfaatkan fenomena PTGS (Post Transcriptional Gene Silencing) yang dapat dilakukan diantaranya dengan konstruk (attn: apa artinya? istilah dapat dialihbahasakan) antisense dan RNAi (RNA interference) yang selanjutnya ditransformasikan pada tanaman. Efektivitas PTGS yang dihasilkan melalui teknik antisense umumnya sekitar 50\%. Knock out gen dengan teknik RNAi bisa lebih tinggi dibanding antisense, misalnya efek silencing beberapa gen (GUS, PVY dan FAD2A12- desaturase) tanaman tembakau, Arabidopsis, tomat (Solanum licopersicum) dan padi (Oryza sativa) mencapai 90-100\% [35].

Selain itu pada tanaman model Arabidopsis transformasi konstruk antisense dapat menurunkan aktivitas enzim 4CL hingga tinggal $8 \%$ dan menyebabkan perubahan rasio G/S lignin [25]. Bahkan pada tanaman kehutanan transgenik subtropis yang cepat tumbuh yaitu aspen (Populus tremuloides) yang mengandung gen penyandi 4CL yang dikonstruksi secara antisense sehingga terjadi downregulated ekspresi 4CL menyebabkan turunnya kadar lignin hingga 45\% dan kadar selulosa meningkat hingga $15 \%$, selain itu terbukti pula memacu pertumbuhan daun, akar dan batang [36, 37]. Keberhasilan tersebut dapat dijadikan acuan penelitian mengenai modifikasi lignin pada tanaman berkayu lainnya. Mengingat peranannya yang penting dalam struktur dinding sel dan ketahanan terhadap hama dan penyakit, penurunan

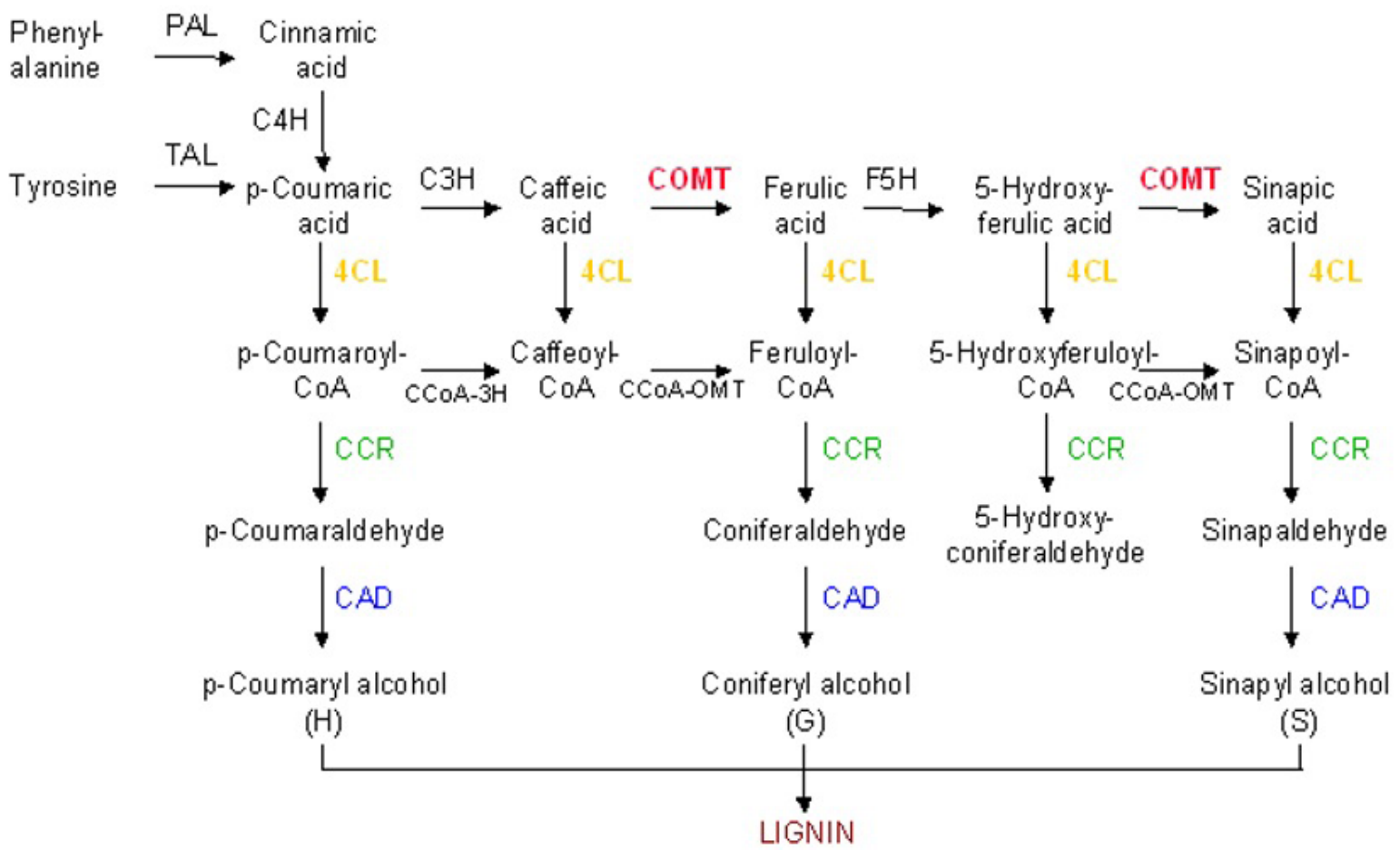

Gambar 1. Jalur biosintesis lignin [20] 
kadar lignin kayu bisa dilakukan hingga batas tertentu yang tidak mengganggu fenotif dan kekuatan pohon.

Percobaan laboratorium untuk mengetahui karakteristik pulping kayu transgenik rendah lignin yang dipelihara di rumah kaca telah dilakukan diantaranya kayu poplar transgenik down regulation $\mathrm{CCR}$ dan $\mathrm{CAD}$, pinus mutan cad dan overekspresi F5H [20]. Pulp Kraft dari kayu transgenik tersebut menunjukkan bilangan Kappa yang rendah (salah satu parameter pulping yang baik) dan berkurangnya kebutuhan bahan kimia untuk proses pulping. Percobaan untuk mengetahui efisiensi pulping pada skala besar (pabrik) masih merupakan kendala karena belum adanya area uji lapangan tanaman kehutanan skala luas yang dapat menghasilkan kayu transgenik rendah lignin yang cukup untuk proses pabrik.

Ketersediaan bibit unggul pohon bahan baku pulp dengan karakteristik kadar lignin rendah tetapi pertumbuhan dan produktivitas kayunya tinggi ataupun kayu dengan komposisi lignin yang lebih reaktif adalah sangat penting untuk memperoleh rendemen pulp yang tinggi tetapi input bahan kimia dan energi yang ekonomis. Pengaruh modifikasi kadar lignin terhadap proses pulping telah diteliti pada tanaman poplar transgenik antisense COMT dan CAD yang menunjukkan bahwa tanaman transgenik rendah lignin memerlukan bahan kimia yang lebih sedikit dan menghasilkan pulp dengan bilangan Kappa yang lebih kecil dibanding kontrol [38]. Demikian juga dengan tanaman transgenik overekspresi gen $\mathrm{F} 5 \mathrm{H}$ memiliki rasio siringil lebih tinggi dan menghasilkan pulp dengan bilangan Kappa lebih rendah dan lebih cerah [20]. Mengingat fungsi lignin yang juga penting untuk tanaman, perbaikan sifat peleraian biomassa dapat dilakukan dengan mengubah komposisi lignin tanpa mengurangi kadar lignin total. Manipulasi rasio monomer lignin lignin dapat mengubah sifat polimer secara keseluruhan [39].

\section{POSISI ORGANISME HASIL REKAYASA} DALAM SISTEM SERTIFKASI KEHUTANAN

Meningkatnya kepedulian masyarakat dunia terhadap lingkungan menyebabkan perlunya penumbuhan industri dan produk hijau (ramah lingkungan). Selain itu pembangunan dibidang industri yang berwawasan lingkungan penting dalam rangka menjamin kelestarian fungsi lingkungan. Pembangunan yang berkelanjutan akan berdampak positif pada kemapanan ekonomi, kelestarian fungsi lingkungan dan fungsi sosial. Pola produksi dan konsumsi yang ramah lingkungan merupakan kunci untuk berlangsungnya pembangunan yang berkelanjutan. Sistem sertifikasi ekolabel merupakan salah satu perangkat lingkungan disamping sistem manajemen lingkungan dan produksi bersih yang dapat pula memberikan nilai tambah atau daya saing ekonomi produk. Lisensi penggunaan tanda ekolabel diberikan oleh lembaga sertifikasi yang terakreditasi oleh Komite Akreditasi Nasional-Badan Sertifikasi Nasional(KAN-BSN).

Proses produksi pulp yang ramah lingkungan seperti modifikasi proses bleaching yang bebas klorin elemental atau biopulping merupakan salah satu implementasi pengembangan industri hijau untuk dapat menggunakan tanda ekolabel. Khusus mengenai Organisme Hasil Modifikasi /OHM (Genetically Modified 
Organism/ GMO) termasuk tanaman rendah lignin masih merupakan wacana perdebatan. Pro dan kontra didalam perdebatan tersebut kebanyakan bukan pada level saintifik, tetapi lebih pada area sosial, etika dan politis. Secara saintifik rekayasa genetik merupakan teknologi breeding yang precise (terarah), jika dibandingkan dengan teknik konvensional yang menyertakan ratusan atau mungkin ribuan gen yang bersilang diantara dua individu untuk mendapatkan suatu sifat yang diinginkan. Dengan teknologi DNA atau transformasi genetik dapat diarahkan sifat yang ingin diubah. Kekhawatiran akan dampak negatif terhadap lingkungan dan kesehatan manusia terutama pangan OHM dapat dimaklumi dan pelepasannya memang harus dilakukan dengan mengedepankan prinsip kehati-hatian melalui serangkaian uji dan analisis risiko. Teknologi DNA juga bisa diarahkan tidak untuk menggantikan pemuliaan konvensional tetapi sebagai pendamping terutama untuk individu-individu yang secara alami ada hambatan atau tidak kompatibel ataupun tidak tersedianya sumber daya genetik untuksifat yang diinginkan.

Dalam sistem sertifikasi kehutanan, tanaman kehutanan hasil rekayasa genetik seperti halnya tanaman pangan OHM masih merupakan perdebatan. Keterbatasan area pengujian lapangan merupakan salah satu hambatan untuk analisis dampak terhadap lingkungan. Badan sertifikasi SFC (Forest Stewardship Council/ FSC) dengan tegas tidak mengijinkan penggunaan organisme hasil modifikasi. Akan tetapi sebaliknya lembaga akreditasi yang lain seperti PEFC (Pan European Forestry Certification), CSA (Canadian Standards Association) dan
LEI (Lembaga Ekolabel Indonesia) tidak mengemukakan secara khusus mengenai teknologi rekayasa genetika [22]. SFC dengan eko-kredibilitasnya memainkan peranan penting untuk mengkaji kembali kriteria yang realistik untuk sertifikasi tanaman kehutanan hasil rekayasa genetik serta memfasilitasi pengujian lapang pohon hasil rekayasa genetik untuk menguji dampaknya terhadap lingkungan [40].

\section{PENUTUP}

Pembangunan industri yang berwawasan lingkungan seyogianya menjadi prinsip dalam upaya pembangunan ekonomi yang berkelanjutan. Walaupun memerlukan investasi instalasi yang sangat tinggi pada awalnya, industri pulp sebagai industri besar dengan peluang keuntungan ekonomi tinggi perlu untuk terus menata pola produksi yang ramah lingkungan melalui penerapan teknologi Total Free Chlorine atau zero AOX ataupun biopulping ataupun biobleaching. Pendekatan secara terintegrasi dalam industri pulp meliputi efisiensi proses produksi, dan pemilihan bahan baku dengan karakteristik yang sesuai diharapkan dapat menuju proses produksi pulp yang efisien dan ramah lingkungan.

Substitusi atau modifikasi pada bahan baku kayu rendah lignin dengan teknologi DNA dapat menjadi alternatif untuk efisiensi proses pulping, yang dapat menurunkan kebutuhan bahan kimia pulping dan bleaching dan berkorelasi dengan penurunan efluen (attn: istilah dapat dialihbahasakan) limbah berbahaya. Walaupun hingga saat ini OHM masih diperdebatkan dan posisinya dalam sistem sertifikasi kehutanan masih belum jelas, setidaknya beberapa jenis tanaman kehutanan 
rendah lignin pada level laboratorium dan rumah kaca di berbagai institusi penelitian sudah tersedia dan siap dilakukan pengujian. Perlu pula adanya kemitraan antara industri pulp dengan institusi yang mengembangkan tanaman transgenik modifikasi lignin untuk mengkaji karakteristiknya.

\section{DAFTAR PUSTAKA}

(1) Teraäs T. 2007. World pulp and paper demand with special emphasis on bleached hardwood market pulp. www. Parliament.tas.gov.aUL.

(2) Kantor Menteri Negara Lingkungan Hidup. 1994. Hasil rapat koordinasi Nasional I. Pengelolaan lingkunagn hidup dan pembangunan berkelanjutan. Jakarta, 22-24 Nopember 1994.

(3) Siagian RM, Roliadi H, Suprapti S, Komarayati S. 2003. Studi peranan fungi pelapuk putih dalam proses biodelignifikasi kayu sengon (Paraserianthes falctaria (L.) Nielsen). Jurnal Ilmu dan Teknologi kayu Tropis. 1(1) : 47-56.

(4) Johnston PA, Stringer R Santilo D, Stephenson AD, Labounskaia IP, McCartney HM. 1996. Towards zero effluent pulp and paper production: The pivotal role of totally chlorine free bleaching. Technical Report 7/96. November 28. 1996. Greenpeace laboratories.

(5) Verma SR. 2014. Lignin genetic engineering for improvement of wood quality: Applications in paper and textile industries, fodder and bioenergy production. South African Journal of Botany. Volume 91: 107125.
(6) Pari G. 1996. Analisis komponen kimia dari kayu sengon dan kayu karet pada beberapa macam umur. Buletin Penelitian Hutan. 14(8): 321-327.

(7) Fengel D, Wegener G. 1995. Kimia Kayu, Ultrastruktur dan Reaksi-reaksi. Sastrohamidjojo H, penerjemah; Prawirohatmodjo S, editor. Yogyakarta: Gajah Mada University Press. Terjemahan dari Wood: Chemistry, Ultrastructure, Reactions.

(8) Syafii W, Siregar IZ. 2006. Sifat Kimia dan Dimensi Serat Kayu Mangium. Acacia mangium Willd.) dari Tiga Provenans. J. Tropical Wood Science \& Technology. 4(1): 28-32.

(9 Hartati NS, Sudarmonowati E, Suharsono, Sofyan K. 2011. Analisis kuantitatif dan uji histokimia lignin sengon (Paraserianthes falcataria). Widyariset, Vol. 14, No.3, Widyariset, Vol. 14, No.3: 526-534.

(10) Davin LB, Lewis NG. 2005. Lignin primary structures and dirigent sites. Current Opinion in Biotechnol 16 (4): 407-415.

(11) Setyorini, D. 2002. Minimisasi limbah dalam industri pulp and paper. Lembaga kajian ekonomi lahan basah. www.terranet.or.id.

(12) Khan WP, Nok AJ. 2003. production and regulation of lignin degrading enzymes from Lentinus squarrosulus (mont.) Singer and Psathyrella atroumbonata Pegler. African Journal of Biotechnology. Vol. 2 (11): 444447.

(13) Soden DM, Dobson DW. 2001. Differential regulationof laccase gene expression in Pleurotus sajor-caju. . 147: 1755-1763. 
(14) Pérez J, Muñoz-Dorado J, de la Rubia T, Martínez J. 2002. Biodegradation and biological treatments of cellulose, hemicellulose and lignin: an overview. Int Microbiol. 5(2):53-63.

(15) Kofujita H, Asada Y, kuwahara M. 1991. Alkyl-aryl cleavage of phenolic b-O-4-lignin substructure model compound by Mn (II)-Peroxidase isolated from Pleurotus ostreatus. Mokuzai Gakkaishi. 37(6): 555-561.

(16) Idiyanti T.1999. Isolasi enzim pelapuk putih isolate PSM01. Prosiding seminar Nasional Kimia VI. Yogyakarta, 24-25 September 1999.

(17) Higuchi T. 1980. Lignin Structure and Morphological Distribution in Plant Cell Walls. Lignin Biodegradation. In . Lignin Biodegradation: Microbiology, Chemistry, and Potential Applications. Kirk, K.T. (ed). CRC Press, Inc. Florida.

(18) Ververis C, Georghiou K, Christodoulakis N, Santas P, Santas R. 2004. Fiber dimensions, lignin and cellulose content of various plant materials and their suitability for paper production. Industrial Crops and Products 19: 245-254.

(19) U.S. Departement of Energi. 2006. Lignocellulosic biomass characteristics. Biofuelsjjoint roadmap. June 2006.

(20) Baucher M., Halpin C, Conil MP, Boerjan W. 2003. Genetic engineering and impact on pulping. Critical Reviews in Biochemistry and Molecular Biology. 38(4): 305-350.

(21) Boudet AM, Kajita S, Pettenati J, Goffner D. 2003. Lignin and lignosellulosics: a better control of synthesis for new and improved uses. Trends in Plant Sci 8(12): 576-581.
(22) Strauss SH., Coventry P, Campbell M, Pryor M, Burley J. 2001. Certification of genetically modified forest plantations. International Forestry Reviews. 3(2): 85-102 The pulp pollution primer. 1999. www.rfu.org.

(23) Haufe KD, Lee SP, Subramaniam R, Douglas CJ. 1993. Combinatorial interaction between positive and negative cis-acting elements control spatial patterns of 4CL1 expression in transgenic tobacco. Plant $J$ 4: 235 253.

(24) Zhang X, Chiang V. 1997. Molecular Cloning of 4-Coumarate:Coenzyme A Ligase in Loblollv Pine and the Roles of This Enzvme in the Biosynthesis of Lignin in Compression Wood. Plant Physiol Vol 113: 65-74.

(25) Lee D, Meyer K, Chapple C, Douglas C. 1997. Antisense suppression of 4-coumarate:coenzyme A ligase activity in arabidopsis leads to altered lignin subunit composition. The Plant Cell 9: 1985-1998.

(26) Zhong R, Morrison WH. 2000. Essential role of caffeoyl coenzyme A O-methyltransferase in lignin biosynthesis in woody poplar plants. Plant Physiol. 124(2): 563-578.

(27) Kao, Y.Y., Harding, S.A. \& Tsai, C.J. 2002. Differential expression of two distinct phenylalanine ammonialyase genes ini condensed tanninaccumulating and lignifying cells of quaking aspen. Plant Physiol. 130(2): 796-807.

(28) Ibrahim RK., Bruneau A. \& Bantignies B. 1998. Plant O-methyltransferases: molecular analysis, common signature and classification. Plant molec Biol. 36: $1-10$. 
(29) He XZ, Reddy JT, Dixon RA. 1998. sterss responses in alfalfa (Medicago sativa L. XXII.). c DNA cloning and characterization of an elicitor inducible isoflavone 7-O-methyltransferase. Plant Molec Biol 36: 43-54.

(30) Allina SM., Pri-hadash A., Theilmann DA, Ellies BE, Douglas CJ. 1998. 4-Coumarate: coenzyme A ligase in hybrid poplar. Properties of native enzymes. Plant Physiol. 116: $743-$ 754.

(31) Ehlting J, Büttner D, Wang Q, Douglas, CJ, Somssich IE, Kombrink E. 1999. Three 4-coumarate: coenzyme A ligase (4CL) in Arabidopsis thaliana reperesent two evolutionary divergent 4CL classes in angiosperm plants. Plant J. 19: 9-20.

(32) Chukovic D, Ehlting J., VanZipffle JA, Douglas CJ. 2001. Sructure and evolution of 4-coumarate: coenzyme A ligase (4CL) gene families. Biol Chem. 382: 645-654.

(33) Ehlting J, Shin JJ Dougla, .J. 2001. Identification of 4-coumarate: coenzyme A ligase (4CL) substrate recognition domains. Plant J. 27: 455465.

(34) Ralph J., Hatfield RD, Sederoff RR , Mackay JJ. 1998. Variations in lignin: what do recent studies on lignin-biosynthetic pathway mutans and transgenics revbeal about lignification?. Research Summaries. US Dairy Forage Research Center: 34-38.

(35) Wesley SV, Hellwell.2001. Construct design for efficient, effective and high throughput gene silencing in plants. Plant J 27(6): 581-590.
(36) Sederoff, R. 1999. Building better trees with antisense. Nat Biotech. August 17: 750-751.

(37) Harding S, Leshkevich J, Chiang V, Tsai C. 2002. Differential substrate inhibition couples kinetically distinct 4-coumarate:coenzyme A ligases with spatially distinct metabolic roles in quaking aspen. Plant Physiol 128(2): 428-438.

(38) Lapierre C, Pollet B, Conil MP, Toval G, Romero J, Pilate G, Leple JC. Boerjan W, Ferret V, Nadai V, Jouanin L. 1999. Structural alterations of lignin in transgenik poplars with depressed cinnamyl alcohol dehtydrogenase or caffeic acid )-methyltransferase activity have an opposite impact on the efficiency of industrial Kraft pulping. Plant Physiol 119: 153-163.

(39) Welker CM, Balasubramanian VK, Petti C, Rai KM, DeBolt S, Mendu V. 2015. Engineering Plant Biomass Lignin Content and composition for Biofuels and Bioproducts. Energies. 8: 654-7676.

(40) Coventry P. 2001. Forest certification and genetically engineered trees: will the two ever be compatible?. O.F.I. Occasional papers No.53. Oxford Forest Institute. 